DOI:10.30857/1813-6796.2018.3.2.

УДК 677.047 .65

АСАУЛЮК Т. С., СЕМЕШКО О. Я., САРІБЕКОВА Ю. Г.

Херсонський національний технічний університет

\title{
ВПЛИВ ХІМІЧНОЇ БУДОВИ ЗШИВАЮЧИХ АГЕНТІВ НА ФІЗИЧНІ ВЛАСТИВОСТІ ПОЛІМЕРНИХ ПЛІВОК НА ОСНОВІ КРОХМАЛЮ
}

Мета. Дослідити вплив активних функиіональних груп зииваючих агентів на фізичні властивості крохмальних полімерних плівок.

Методика. Використані стандартизовані методики дослідження показників фізичних властивостей полімерних плівок.

Результати. В роботі наведені результати дослідження впливу зииваючих агентів різної хімічної будови на фізико-механічні властивості, відношення до дії атмосферної вологи та стійкість до мокрих обробок крохмальних полімерних плівок. Встановлено покращення досліджуваних показників плівок при застосуванні L-винної кислоти.

Наукова новизна. Доведено, щзо застосування L-винної кислоти в якості зииваючого агенту дозволяє поліпшити фізичні властивості полімерних плівок на основі крохмалю.

Практична значимість. Отримані результати експерименту мають практичне значення для розробки нових екологічно безпечних полімерних матеріалів.

Ключові слова: полімерні плівки, крохмаль, зшиваючі агенти, фізичні властивості.

Вступ. На сьогоднішній день спостерігається підвищення інтересу до текстильних матеріалів, що мають комплекс спеціальних властивостей. Надання спеціальних властивостей текстильним матеріалам досягається за рахунок створення на поверхні тканин полімерних покриттів різного призначення [1-2].

Зростаючий попит на високу хімічну стійкість і механічну міцність, а також обмеження, що пов'язані з викидами летких органічних сполук, призвели до необхідності розробки нових полімерних композицій для текстильної промисловості. У зв'язку з цим дослідження, направлені на створення екологічно безпечних полімерних захисних систем $\epsilon$ актуальними.

Перспективним є застосування полімерних композицій на основі природних полімерів [3-9]. В якості природних плівкоутворюючих речовин широке застосування мають полісахариди, зокрема крохмаль. Крохмаль $є$ доступною поновлюваною i екологічно безпечною сировиною. Недоліком індивідуальних крохмальних полімерних плівок $\epsilon$ недостатня механічна міцність, жорсткість, гідролітична нестабільність. У зв'язку з цим до складу полімерної композиції на основі крохмалю окрім пластифікатору вводять зшиваючі агенти, які повинні забезпечити хімічну взаємодію між пластифікатором і крохмалем за допомогою ковалентного зв'язку.

Постановка завдання. В якості екологічно безпечних зшиваючих агентів відомо застосування багатоосновних карбонових кислот та їх похідних. Авторами [10, 11] запропоновано використання лимонної кислоти в складі крохмальних полімерних композицій з метою утворення просторово зшитих трьохвимірних структур. Слід зазначити, що лимонна кислота за хімічною будовою є трьохосновною карбоновою гідроксікислотою. Наявність трьох карбоксильних груп, а також гідроксігрупи може бути причиною меншої 
конфірмаційної рухливості лимонної кислоти в процесі формування просторово зшитої структури з пластифікатором і крохмалем.

Враховуючи вище викладене, основним завданням $є$ дослідження впливу активних функціональних груп зшиваючих агентів на зміну фізичних властивостей полімерних плівок на основі крохмалю.

Результати дослідження. У дослідженні в якості плівкоутворюючої речовини використовується картопляний крохмаль, в якості пластифікатору - гліцерин. В якості зшиваючих агентів обрані янтарна кислота, янтарний ангідрид, L-винна кислота (діоксіянтарна кислота). Для порівняння результатів проведено дослідження 3 використанням лимонної кислоти.

Полімерні плівки виготовляються з водного розчину. Зшиваючий агент вводиться у кількості $1 \%$ від маси композиції. Розварювання розчину проводиться при $85-90^{\circ} \mathrm{C}$ протягом 30 хв. Сформовані плівки висушуються при $60^{\circ} \mathrm{C}$ з наступною термообробкою при $150^{\circ} \mathrm{C}$.

На першому етапі роботи було визначено вплив обраних зшиваючих агентів на зміну таких фізичних властивостей крохмальних плівок, як товщина, поверхнева щільність $\mathrm{i}$ зовнішній вигляд. Результати випробувань наведені в таблиці 1.

Таблиця 1

Вплив хімічної будови зшиваючих агентів на фізичні властивості крохмальних плівок

\begin{tabular}{|l|c|c|c|}
\hline \multicolumn{1}{|c|}{ Зшиваючий агент } & Товщина, мкм & $\begin{array}{c}\text { Поверхнева } \\
\text { щільність, } / \mathrm{m}^{2}\end{array}$ & Зовнішній вигляд \\
\hline Без зшиваючого агенту & 190 & 190 & прозора, жорстка \\
\hline Лимонна кислота & 130 & 130 & мутна, еластична \\
\hline Янтарна кислота & 120 & 158 & білувата, еластична \\
\hline Янтарний ангідрид & 110 & 158 & білувата, еластична \\
\hline L-винна кислота & 110 & 160 & прозора, еластична \\
\hline
\end{tabular}

Аналіз результатів експерименту (табл. 1) свідчить про зниження товщини і поверхневої щільності зразків плівок зі зшиваючими агентами порівняно 3 крохмальною плівкою без зшиваючого агенту. Найменше значення поверхневої щільності спостерігається при введенні до складу композиції лимонної кислоти. Всі досліджувані зшиваючі агенти сприяють підвищенню еластичності крохмальних полімерних плівок. Однак при використанні янтарної кислоти і янтарного ангідриду полімерна плівка має білуватий колір, що можна пояснити утворенням на їі поверхні кристалів янтарної кислоти під час сушіння та термообробки. Введення у композицію L-винної кислоти дозволяє отримувати прозору, еластичну крохмальну плівку, на відміну від білуватих полімерних матеріалів зі вмістом янтарної кислоти та янтарного ангідриду. При цьому товщина та поверхнева щільність змінюються в незначній мірі.

Важливими характеристиками крохмальних полімерних покриттів є відношення до дії атмосферної вологи та стійкість до мокрих обробок. У зв'язку з цим на наступному етапі роботи було визначено вплив зшиваючих агентів на показники гігроскопічності, водопоглинання і гідролітичної стабільності. Результати експерименту представлені на рис. $1,2$. 


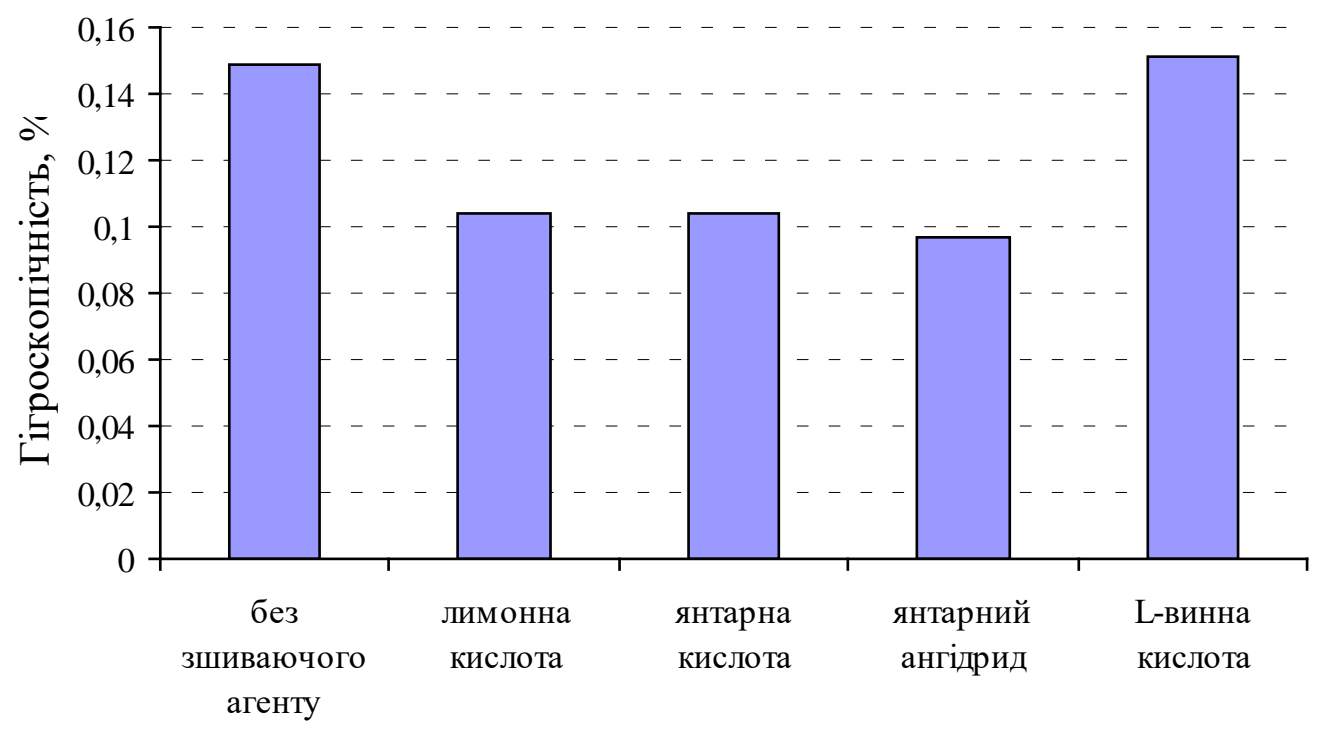

Рис. 1. Вплив зшиваючих агентів на гігроскопічність крохмальних плівок

Коливання атмосферної вологи може призводити до зміни вмісту вологи у крохмальних плівках, що позначається на їх технологічних властивостях. Отримані результати експерименту (рис. 1) показують, що при атмосферній вологості 100\% гігроскопічність крохмальних плівок, що містять лимонну і янтарну кислоту, знижується на 30\% у порівнянні 3 крохмальною плівкою без зшиваючого агенту. При застосуванні янтарного ангідриду спостерігається зменшення гігроскопічності крохмальної плівки на 35\%. Введення до складу композиції L-винної кислоти призводить до незначної зміни досліджуваного показника крохмальної плівки.

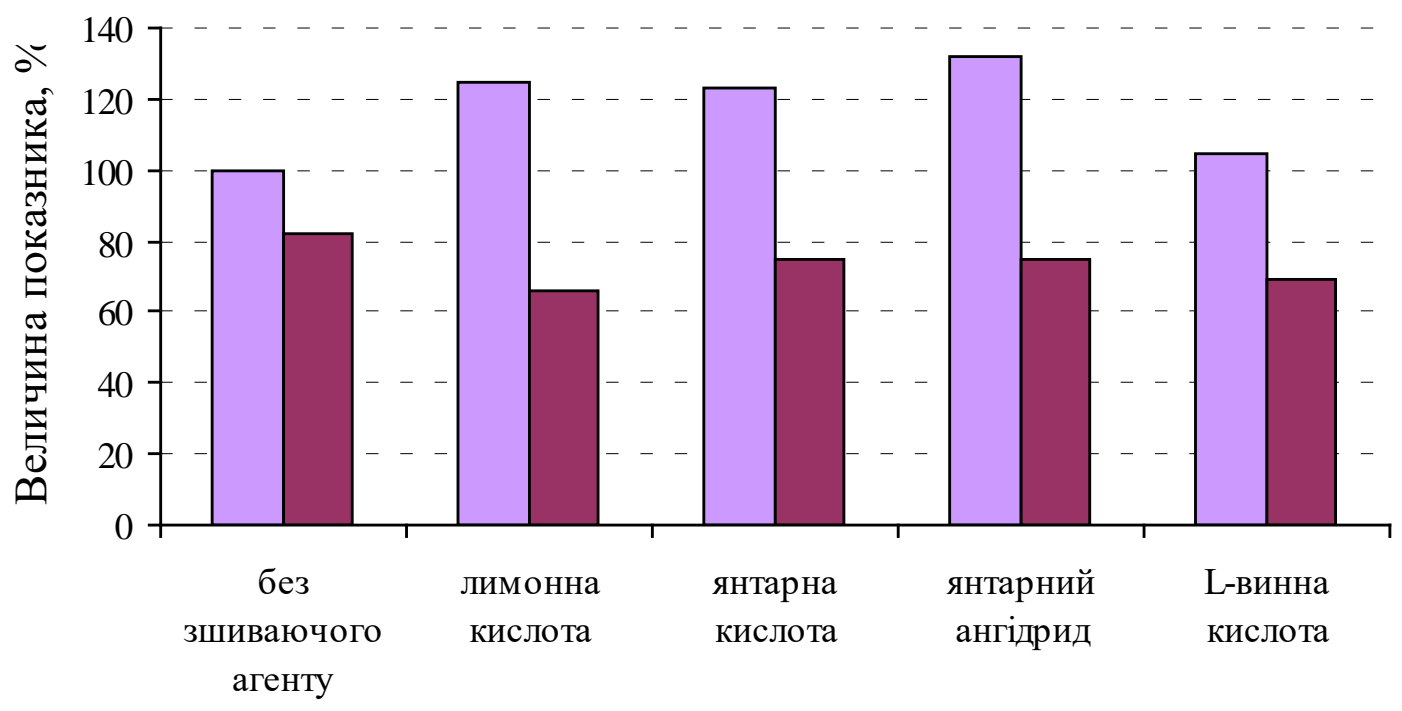

Водопоглинання $\square$ Гідролітична стабільність

Рис. 2. Вплив зшиваючих агентів на відношення крохмальних плівок до мокрих обробок 
Дані, представлені на рис. 2, свідчать про підвищення водопоглинання крохмальних плівок при введенні до їх складу лимонної кислоти, янтарної кислоти і янтарного ангідриду на 25\%, 23\% і 32\% відповідно. Використання в якості зшиваючого агенту L-винної кислоти призводить до підвищення досліджуваного показника на 5\%.

Гідролітична стабільність характеризує ступінь стійкості полімерної плівки до дії води. Отримані результати експерименту (рис. 2) показують, що використання досліджуваних зшиваючих агентів у складі полімерної композиції спричиняє зниження стійкості крохмальних плівок до гідролітичної деструкції на 7,3-15,6\%. Слід зазначити, що найнижчий ступінь стійкості до гідролітичної деструкції має крохмальна плівка зі вмістом лимонної кислоти - 15,6\%.

Порівняльний аналіз отриманих результатів проведеного експерименту показав, що використання в якості зшиваючого агенту янтарного ангідриду призводить до аналогічних змін властивостей крохмальної плівки як і при використанні відповідної карбонової кислоти. Застосування L-винної кислоти у складі полімерної композиції призводить до незначного підвищення гігроскопічності та водопоглинання полімерного матеріалу в порівнянні 3 індивідуальною крохмальною плівкою, при цьому гідролітична стабільність знижується на 12,4\%. Зниження показника гідролітичної стабільності в порівнянні 3 використанням янтарної кислоти та відповідного ангідриду може бути пов'язане 3 наявністю двох гідроксігруп у складі L-винної кислоти, оскільки аналогічна тенденція спостерігається у випадку лимонної кислоти, яка також містить гідроксігруппу.

Висновки. Таким чином, результати проведеного дослідження доводять, що застосування в складі крохмальної полімерної композиції в якості зшиваючого агенту Lвинної кислоти дозволяе отримати прозорі еластичні крохмальні плівки, які характеризуються меншим водопоглинанням та більшою гідролітичною стабільністю в порівнянні з крохмальними плівками, що містять лимонну кислоту. Подальші дослідження будуть спрямовані на визначення синергічного впливу зшиваючих агентів на властивості крохмальних полімерних матеріалів.

\section{Література}

1. Onar N. Development of water-, oil-repellent and flame-retardant cotton fabrics by organic-inorganic hybrid materials [Text] / N. Onar, G. Mete // Journal of the Textile Institute. - 2016. - Vol. 107, Issue 11, P. 1463-1477. DOI: 10.1080/00405000.2015.1128208

2. Camlibel N.O. Antibacterial, UV protection, flame retardancy and coloration properties of cotton fabrics coated with polyacrylate polymer containing various iron ores [Text] / N.O. Camlibel, B. Arik, O. Avinc // Journal of the Textile Institute. - 2018. DOI: 10.1080/00405000.2018.1423937

3. Pan H. Layer-by-layer assembled thin films based on fully biobased polysaccharides: Chitosan and phosphorylated cellulose for flame-retardant cotton fabric [Text] / H. Pan, L. Song, L. Ma, Y. Hu // Cellulose. - 2014. - Vol. 21, Issue 4. - P. 2995-3006. DOI: $10.1007 / \mathrm{s} 10570-014-0276-5$

\section{References}

1. Onar, N., Mete, G. (2016). Development of water-, oil-repellent and flame-retardant cotton fabrics by organic-inorganic hybrid materials. Journal of the Textile Institute. 107, 11, 14631477. DOI: $10.1080 / 00405000.2015 .1128208$

2. Camlibel, N.O., Arik, B., Avinc, O. (2018). Antibacterial, UV protection, flame retardancy and coloration properties of cotton fabrics coated with polyacrylate polymer containing various iron ores. Journal of the Textile Institute. DOI: 10.1080/00405000.2018.1423937

3. Pan, H., Song, L., Ma, L., Hu, Y. (2014). Layer-by-layer assembled thin films based on fully biobased polysaccharides: Chitosan and phosphorylated cellulose for flame-retardant cotton fabric. Cellulose, 21, 4, 2995-3006. DOI: 10.1007/s10570-014-0276-5 
4. Jimenez M. Microintumescent mechanism of flame-retardant water-based chitosan-ammonium polyphosphate multilayer nanocoating on cotton fabric [Text] / M. Jimenez, T. Guin, S. Bellayer, J.C. Grunlan // Journal of Applied Polymer Science. 2016. - Vol. 133, Issue 32. DOI: 10.1002/app.43783

5. Su C.H. Preparation of Cotton Fabric Using Sodium Alginate-Coated Nanoparticles to Protect Against Nosocomial Pathogens [Text] / C.H. Su, V. Kumar, S. Adhikary, P. Anbu, P. Velusamy, P. Kannaiyan // Biochemical Engineering Journal. 2016. - Vol. 117. - P. 28-36. DOI: 10.1016/j.bej.2016.10.020

6. Scacchetti F.A.P. Thermal and antimicrobial evaluation of cotton functionalized with a chitosanzeolite composite and microcapsules of phase-change materials [Text] / F.A.P. Scacchetti, E. Pinto, G.M.B. Soares // Journal of Applied Polymer Science. - 2017. - Vol. 135, Issue 15. - P. 46135. DOI: 10.1002/app.46135

7. Arza C.R. New biobased non-ionic hyperbranched polymers as environmentally friendly antibacterial additives for biopolymers [Text] / C.R. Arza, S. İlk, D. Demircan, B. Zhang // Green Chemistry. - 2018. Vol. 20, Issue 6. - P. 1238-1249. DOI: 10.1039/C7GC03401F

8. Muzaffar S. Synthesis and Characterization of Aqueous Chitosan-polyurethanes Dispersion for Textile Applications with Multipurpose Performance Profile [Text] / S. Muzaffar, I. Ahmad, M. Zuber, M. Shahid, H. Bhatti // Fibers and Polymers. - 2018. Vol. 19, Issue 3. - P. 587-598. DOI: 10.1007/s12221018-7896-6

9. Arshad N. Synthesis, characterization of novel chitosan based water dispersible polyurethanes and their potential deployment as antibacterial textile finish [Text] / N. Arshad, K.M. Zia, F. Jabeen, M.N. Anjum, N. Akram, M. Zuber // International Journal of Biological Macromolecules. - 2018. - Vol. 111. - P. 485-492. DOI: 10.1016/j.ijbiomac.2018.01.032

10.Шубина Е.В., Никифоров А.Л., Мельников Б.Н. Новая технология малосминаемой отделки текстильных материалов [Текст] / Е.В. Шубина, А.Л. Никифоров, Б.Н. Мельников // Изв. вузов. Технология текстильной промышленности. - 2003. - №1(270). - C. 73-76.

11.Scacchetti F.A.P. Preparation and characterization of cotton fabrics with antimicrobial properties through the application of chitosan/silver-zeolite film [Text] / F.A.P. Scacchetti, E. Pinto, G.M.B. Soares // Procedia Engineering. - 2017. - Vol. 200. - P. 276-282. DOI: 10.1016/j.proeng.2017.07.039
4. Jimenez, M., Guin, T., Bellayer, S., Grunlan, J.C. (2016). Microintumescent mechanism of flame-retardant water-based chitosan-ammonium polyphosphate multilayer nanocoating on cotton fabric. Journal of Applied Polymer Science, 133, 32. DOI: $10.1002 / a p p .43783$

5. Su, C.H., Kumar, V., Adhikary, S., Anbu, P., Velusamy, P., Kannaiyan, P. (2016). Preparation of Cotton Fabric Using Sodium Alginate-Coated Nanoparticles to Protect Against Nosocomial Pathogens. Biochemical Engineering Journal, 117, 28-36. DOI: 10.1016/j.bej.2016.10.020

6. Scacchetti, F.A.P., Pinto E., Soares, G.M.B. (2017). Thermal and antimicrobial evaluation of cotton functionalized with a chitosan-zeolite composite and microcapsules of phase-change materials. Journal of Applied Polymer Science, 135, 15, 46135. DOI: 10.1002/app.46135

7. Arza, C.R., İlk, S., Demircan, D., Zhang, B. (2018). New biobased non-ionic hyperbranched polymers as environmentally friendly antibacterial additives for biopolymers. Green Chemistry, 20, 6, 1238-1249. DOI: 10.1039/C7GC03401F

8. Muzaffar, S., Ahmad, I., Zuber M., Shahid, M., Bhatti H. (2018). Synthesis and Characterization of Aqueous Chitosanpolyurethanes Dispersion for Textile Applications with Multipurpose Performance Profile. Fibers and Polymers, 19, 3, 587-598. DOI: 10.1007/s12221-018-7896-6

9. Arshad, N., Zia, K.M, Jabeen, F., Anjum, M.N., Akram, N., Zuber, M. (2018). Synthesis, characterization of novel chitosan based water dispersible polyurethanes and their potential deployment as antibacterial textile finish. International Journal of Biological Macromolecules, 111, 485-492. DOI: 10.1016/j.ijbiomac.2018.01.032

10. Shubina, E.V., Nikiforov, A.L., Melnikov, B.N. (2003) Novaya tekhnologiya malosminayemoy otdelki tekstil'nykh materialov [The new technology of anticrease finish of textile materials]. Izvestiya Vysshikh Uchebnykh Zavedenii, Seriya Teknologiya Tekstil'noi Promyshlennosti, 1(270), 73-76.

11. Scacchetti, F.A.P., Pinto E., Soares, G.M.B. (2017). Preparation and characterization of cotton fabrics with antimicrobial properties through the application of chitosan/silver-zeolite film. Procedia Engineering, 200, 276-282. DOI: 10.1016/j.proeng.2017.07.039 
ORCID: http://orcid.org/0000- 0001-5961-6895 tatisevna@gmail.com
ORCID: http://orcid.org/0000-0002-8309-5273 solgaya@gmail.com Kherson National Technical University

SARIBYEKOVA YULIA

ORCID: http://orcid.org/0000-0001-6430-6509 ysaribyekova@gmail.com Kherson National Technical University

\section{ВЛИЯНИЕ ХИМИЧЕСКОГО СТРОЕНИЯ СШИВАЮЩИХ АГЕНТОВ НА ФИЗИЧЕСКИЕ СВОЙСТВА ПОЛИМЕРНЫХ ПЛЕНОК НА ОСНОВЕ КРАХМАЛА АСАУЛЮК Т. С., СЕМЕШКО О. Я., САРИБЕКОВА Ю. Г. \\ Херсонский национальный технический университет}

Цель. Исследовать влияние активных функииональных групп сшивающих агентов на физические свойства крахмальных полимерных пленок.

Методика. Применены стандартизированные методики исследования показателей физических свойств полимерных пленок.

Результаты. В работе приведены результаты исследования влияния сшиваютих агентов разного химического строения на физико-механические свойства, отнотение $\kappa$ действию атмосферной влаги и устойчивость к мокрым обработкам крахмальных полимерных пленок. Установлено улучшение исследуемых показателей пленок при использовании L-винной кислоты.

Научная новизна. Доказано, что применение L-винной кислоты в качестве сшивающего агента позволяет улучшить физические свойства полимерных пленок на основе крахмала.

Практическая значимость. Полученные результаты эксперимента имеют практическое значение для разработки новых экологически безопасных полимерных материалов.

Ключевые слова: полимерные пленки, крахмал, сшивающие агенты, физические свойства.

\section{EFFECT OF THE CHEMICAL STRUCTURE OF CROSSLINKING AGENTS ON THE PHYSICAL PROPERTIES OF POLYMER FILMS BASED ON STARCH ASAULYUK T. S., SEMESHKO O. Ya., SARIBYEKOVA Yu. G. Kherson National Technical University}

Purpose. To study the effect of active functional groups of cross-linking agents on the physical properties of starch polymer films.

Methodology. Standardized methods for studying the indicators of physical properties of polymer films have been applied.

Findings. The paper presents the results of the study of the effect of crosslinking agents of different chemical structure on the physicomechanical properties, the influence of atmospheric moisture and the resistance to wet treatments of starch polymer films. An improvement in studied parameters of the films with the use of L-tartaric acid was established.

Originality. It has been proved that the use of L-tartaric acid as a crosslinking agent makes it possible to improve the physical properties of polymer films based on starch.

Practical value. The obtained experimental results are of practical importance for the development of new environmentally friendly polymer materials.

Keywords. polymer films, starch, crosslinking agents, physical properties. 